\title{
HANSJÜRGEN VERWEYEN
}

Social contract among devils 


\title{
SOCIAL CONTRACT AMONG DEVILS
}

\author{
Hansjürgen Verweyen
}

At a time of utter confusion, when the standards of efficiency are taken from the high executives, but the high executives fail; when the slogan "publish or perish" has become an indicator that even the teacher in the humanities, who should be concerned with perspectives reaching beyond the merely fashionable, is not exempt from a Darwinian model of competition, the life and work of Imanuel Kant can be a symbol of hope. His life was said to pass like the most regular of regular verbs. And if you know nothing else of Kant, you will have heard that the housewives of Königsberg used to set their clocks by the regular afternoon walk he took. He seldom left this city where he was born and died, and not once in his whole life did he leave the province of Königsberg.

This is not the style an academic should adopt who wishes to get a tenured position today. It even took the University of Königsberg fifteen years after Kant had earned his doctoral degree before they appointed him to a chair in philosophy. For those among us who feel already somewhat beyond the time bracket which allows for competition and efficiency, it may be consoling to know that Kant published his Critique of Pure Reason, the Copernican work in philosophy which molded the thought of all centuries to come, at the age of 57. The famous little work which shall provide us with the focal text for this lecture, Kant's essay On Eternal Peace, appeared in 1795 when he was 71.

The essay begins:

\section{"To Eternal Peace"}

Whether the above satirical inscription, once put by a certain Dutch innkeeper on his signboard on which a graveyard was painted, holds of men in general, or particularly of the heads of states who are never sated with war, or perhaps of those philosophers who are dreaming that sweet dream of peace, may remain undecided ...'

This example shows that, although Kant's style may have been dry, it did not lack a certain, as I may say, Hitchcockian way of wit. The same brand of black humor is exhibited in the passage which shall serve as a starting point for my reflections, cited from paragraph six of the Critique of Practical Reason:

Suppose that someone says his lust is irresistible when the desired object and opportunity is present. Ask him whether he would not control his passion if, in front of the house where he has this opportunity, a gallows were erected on which he would be hanged immediately after gratifying his lust. We do not have to guess very long what his answer would be. But ask him whether he thinks it would be possible for him to overcome his love of life, however great it may be, if his sovereign threatened him with the same sudden death unless he made a false deposition against an honorable man whom the ruler wished to destroy under a plausible pretext. Whether 
he would or not he perhaps will not venture to say; but that it would be possible for him he would certainly admit without hesitation. He judges, therefore, that he can do something because he knows that he ought, and he recognizes that he is free - a fact which, without the moral law, would have remained unknown to him. ${ }^{2}$

There is, incidentally, a scene rather similar to Kant's description of a man faced with the gallows, in a text from a compatriot of Hitchcock. David Hume, when discussing the question "Of Liberty and Necessity," in Section VIII of his famous Inquiry Concerning Human Understanding, illustrates his point that so-called voluntary actions follow the same rules as natural causes and effects. He refers to a prisoner who,

"when conducted to the scaffold, foresees his death as certainly from the constancy and fidelity of his guards as from the operation of the ax or wheel. His mind runs along a certain train of ideas: the refusal of the soldiers to consent to his escape; the action of the executioner; the separation of the head and body; bleeding, convulsive motions, and death. Here is a connected chain of natural causes and voluntary actions, but the mind feels no difference between them in passing from one link to another ..."3 I must admit that Hume is more congenial to the famous producer of horror movies. Kant, who has been strongly influenced by Hume, may even have chosen his example for the sole reason of showing more forcefully that he wants to speak in this passage on the same point of freedom, although from quite a different angle than the Empiricist philosopher. D. Hume discusses human actions from the point of view of the sociologist who tries to submit "liberty" to the general pattern of cause and effect in order to gain solid scientific criteria of observation. These are matters dealt with in Kant's Critique of Pure (i.e., pure theoretical) Reason which definitely deepens but does not contradict the perspective of Hume. In the Critique of Practical Reason, Kant's most fundamental work on ethics, human action is viewed from inside, so to speak, namely in its being faced with the "categorical imperative," an unconditional call to act morally. I have chosen this particular passage from paragraph six of the second Critique because it illustrates rather well the different modes of possible motivation.

The man who claims to be fully determined by his sexual desire, one of the strongest natural drives, must admit that this motive force can easily be overruled by a stronger concern: the desire to live. It is over and against this most powerful of all natural drives that Kant outlines the impact of quite a different power which declares its demands not in the form of a "must," but of an "ought," and yet with a forcefulness that transcends all natural determination. The man faced with the call to act morally may "not venture to say" whether he will not eventually give in to the prince for fear of death and commit a lie which will bring an honorable man to death. But he knows that he ought not to, and by the same token recognizes the possibility of his freedom and the nobility man has over the rest of nature. 
It is for the sake of emphasizing this nobility of man that Kant's entire work, from the most abstract deductions of theoretical reason to his concrete suggestions in the context of political philosophy, is written.

The essay, On Eternal Peace, belongs to those writings in which Kant has proposed concrete ideas for the improvement of politics and rights. In the framework of my paper, I am not going to discuss the entire content of this work. Kant's main point is the stress on three necessary steps toward the achievement of perpetual peace. His "First Definitive Article for an Eternal Peace" states that "The civil constitution in every state shall be republican." Kant does not favor the type of democratic government which has been adopted by most [of the] western societies today, which at his time, however, was just beginning to prove its feasibility in the United States of America. He prefers what we call a "constitutional monarchy," but emphasizes the need for the separation of the legislative and executive powers and the representation of the people in the government. "Democracy" in the classical sense in which Kant uses the term, i.e., a system where all are directly governed by all, would lack this representation and the separation of the two powers, and thus be "despotism." The kind of republicanism which had just developed out of the French Revolution seemed only to be another proof for the ancient Greek theory of democracy as a form of despotic government. Kant's "Second Definitive Article" says that the law of nations, or international law, "shall be based upon a federalism of free states." Some of his ideas on such a federalism of freely united nations have become incorporated into the twentieth century's attempts in this direction. The Third Article restricts what Kant calls the "right of world citizenship" to conditions of universal hospitality, the fundamental presupposition for those who want to enter a social contract.

It is the "First Supplement" to these articles upon which our reflections shall focus, "On the guarantee of eternal peace." Before we turn to a more detailed discussion of the philosophical implications of this "Supplement," which are not easy to grasp, let me quote the crucial passage from which the title of this paper has been drawn.

The problem of establishing a state can be solved even for a people of devils, if only they have intelligence, though this may sound harsh. The problem is: 'To organize a multitude of rational beings who demand universal laws for their preservation, but each of whom is secretly inclined to exempt himself from them, and to establish their constitution in such a way that, although their private intentions conflict, they check each other with the result that their public conduct is the same as if they have no such evil intentions.' ${ }^{4}$

This theory of a social contract among rational beings with a natural inclination toward egotism is not quite new. In Plato's Republic one of the participants in the dialogue, Glaucon, reports the opinion of common sense "on what justice is and whence it comes":

They say . . that to be unjust is good, and to suffer injustice is bad, but the excess of evil in suffering injustice is greater than the excess of good 
in being unjust; so that when people do and suffer injustice in dealing with one another, and taste both, those who cannot both escape the one and take the other think it profitable to make an agreement neither to do nor to suffer injustice; from this they begin to make laws and compacts among themselves, and they name the injunction of the law lawful and just. This, they say, is the origin and nature of justice, which is something between the best, namely to do wrong and not to pay for it, and the worst, to suffer wrong and not to be able to get vengeance. ${ }^{5}$

Of course, Plato does not make this theory of justice his own. Where both the natural and the social cosmos were believed to be rooted in a divine order and this was the case in Greek antiquity as well as in the Christian world until the end of the Middle Ages - a mere mechanistic or technical outlook at the solution of social problems without the taking into account of fundamental moral laws and religious institutions was possible only as a theory of outsiders. The question of freedom and justice in general was concerned not primarily with the individual, but with man in the totality of his inherited relationships. The emperor, the king, to the medieval mind, were in possession of their power by divine institution. Social order was a complicated network determined in the permanent struggle between papal and secular authorities, but it was not believed to be based upon human convention and mere expediency.

Things changed rapidly with the beginning of Modern Times, when the former privileges and institutions were questioned and the assertion of the "natural" rights of each individual became the starting point for a basically technicallyorientated social and political philosophy. The fundamental problem of political theory was now: How to construct a just order out of a given multitude of "individuals" — the "atoms," "the last indivisible elements of society — who all are to share the same rights?

The modern theories of a social contract still exhibit a large variety. Beside thinkers who have not yet fully freed themselves from medieval conceptions there are Locke and Rousseau who - despite accidental allusions to "the law of nature" or divine order - both present a principally modern philosophy, but reckon with a basic goodness and morality of man in their political theories. However, there are also Hobbes and Adam Smith who adopt the modern starting point of a sum total of human atoms in its most rigoristic form, i.e., in abstraction from all moral qualifications. According to Hobbes, it is man's "perpetual and restless desire of power that ceaseth only in death" which constitutes the state of nature as a "war of all against all" and makes people, out of their constant fear of death, enter a social contract with an absolutist regime as its consequent result.

Adam Smith exhibits - on the same basic premises - the most radical theory of liberalism. As early as in 1749 , he stated in a lecture the essence of his developed doctrine, as expounded in the Wealth of Nations:

Projectors disturb nature in the course of her operations on human affairs, and it requires no more than to leave her alone and give her fair play in the pursuit of her ends that she may establish her own designs.? 
Kant's idea of a "social contract among devils" is no less radical in its abstraction from all presuppositions of morality than the political theories of Hobbes, Adam Smith, or Machiavelli before them. The most puzzling thing about this ideal arrangement, however, is that, while the former writers readily contented themselves with a legalistic outlook upon man in his egotistic attitudes and the usefulness of this behavior in the natural competition of forces, Kant offers his idea as part of a system of morality which is far beyond the reach of any earlier theoretician of the social contract. I would like to discuss the problematic involved in this strange correlation of legality and morality in Kant's philosophy in two major steps, each time by outlining the basic impact that Kant's theory has left upon his successors.

I. What is the value of the theory of an automatic construction of a just society out of the free interplay of enlightened egotism, considered in itself?

II. What is its place within a systematic conception of a universal moral order?

\section{The theory of an automatic adjustment} of opposed private interests to social order

Kant claims in his essay that the problem of constructing a just constitution through the mutual arrangement of opposite interests is solvable, but he confines himself to a few hints only as to how this arrangement could, or as he even asserts, will necessarily come about. He says for instance:

Even if a people were not forced by internal discord to submit to public laws, war would compel them to do so, for ... nature has placed each people near another which presses upon it, and against this it must form itself into a state in order to defend itself. ${ }^{8}$

And a few pages later:

The spirit of commerce, which is incompatible with war, sooner or later gains the upper hand in every state. As the power of money is perhaps the most dependable of all the powers $(\ldots$ ) included under the state power, states see themselves forced, without any moral urge, to promote honorable peace and, by mediation, to prevent war wherever it threatens to break out. ${ }^{9}$

The first systematic - and one may also say, the most consistent - attempt at fulfilling the promise of such a rational construct of order on the sole basis of conflicting private interests was not presented by Kant himself, but by J. G. Fichte who, according to his clearly stated purpose, did intend nothing else with his philosophy but to fill the lacunae that Kant had left open. Independently from Kant, Fichte wrote his Science of Rights which appeared one year later than Kant's essay, in 1796/97.

It took Fichte much longer than his immediate successors and critics in the philosophical tradition of "German Idealism," Schelling and Hegel, 10 to realize that his apriori construction of a just society did not fulfill the necessary 
requirements, and that all similar attempts must needs fail, in the final analysis, because the problem of who is to check the highest power cannot be solved in a more than approximative and relatively satisfactory manner.

Kant has contented himself with such an approximative solution. Already in the Sixth Thesis of his short sketch, Idea for a Universal History from a Cosmopolitan Point of View of 1784, he had stated that the task to find a highest master who would be

just in himself, and yet a man ... is the hardest of all; indeed, its complete solution is impossible, for from such crooked wood as man is made of, nothing perfectly straight can be built. Only the approximation toward this idea is imposed upon us by nature."

In concluding his "First Supplement" of his essay On Eternal Peace, "On the guarantee of eternal peace," he concedes that the mechanism of human passions does not guarantee perpetual peace

with sufficient certainty for us to predict the future in any theoretical sense, but adequately from a practical point of view, making it our duty to work toward this end, which is not just a chimerical one. ${ }^{12}$

Aside from the question as to what weight Kant himself attributed to his theory, it is interesting to note, from the viewpoint of the history of philosophy, that, as soon as the German Idealists discovered that a full-proof solution to the problems of the social contract is not possible, they gave up this idea altogether. For an absolute-minded philosopher as Fichte, the discovery of the merely relative value of any such solution might have been a sufficient reason to abandon this line of political theorizing unreluctantly. Not so for Hegel who, from the outset of his philosophy, incorporated the contingency and relativity of history in his dialectical method. There must have been another reason for his parting with the idea of a social contract than its merely relative sufficiency. This brings us to our next and more difficult question.

\section{The place of the theory of an automatic appeasement of conflicting interests within a system of universal moral order}

For an adequate grasp of this question in respect to Kant's concept of morality, at least a superficial acquaintance with his theory of the "postulates of practical reason" is indispensable. There are three basic premises of this theory. (1) The "categorical imperative" to act morally is unconditional and universal in its application. (2) This moral demand, although its primary direction is toward the just intention of the rational subject, not toward a specific objective result of the moral action, is not confined to an "ethics of pure intentionality," as if the moral subject could be indifferent to the accomplishment of his action in the real, objective world. The final goal of morality is the submission of the whole universe to the demands of practical, moral reason. Kant calls this ultimate goal "the highest good." (3) The certitudes of theoretical and practical reason, according to Kant, are of a different order. The moral subject needs no support of empirical evidence in order to be certain of the ethical demands. A 
consideration as to whether the probable objective result of his action is worth the moral effort would only prove his immorality. On the other hand, evidences of the moral order give us no right to draw conclusions from them in respect to matters of fact. The statement: "Nicht sein kann, was nicht sein darf" (What must not be, cannot be) is obviously unrealistic. As much as the moral law is independent from natural determination, the laws of nature are independent from the moral order, in this present stage of the world.

On the basis of these premises the "categorical imperative" to strive toward the accomplishment of "the highest good" in the world implies two "postulates," i.e., evidences of the moral order, not of theoretical knowledge concerning matters of fact. (1) Because the categorical demand does not cease to oblige the moral subject until the final goal is achieved, the existence of the addressee of the call must be guaranteed as long as the end is not reached lest the imperative becomes absurd. This implies, since the ultimate goal can only be approximated, but never totally accomplished by man, that the human soul is immortal. (2) The moral law demands the accomplishment of the "highest good" in the world of objectivity. An evidence of the moral order, however, does not legitimate in any way a theoretical assumption concerning matters of fact - in this case, concerning the ultimate arrangement of matters of fact in harmony with the moral law. Therefore, we postulate a final guarantor of the possibility of the highest good, beyond the faculty of moral man, again lest the categorical imperative becomes absurd. Moral man necessarily postulates the existence of God who combines in himself perfection in the realm of moral law with the absolute power over the laws of nature.

Returning to our specific question with regard to the place of the theory of a "social contract among devils" in a system of morality, it is interesting to observe that Kant had formulated an additional postulate as it seems, ..., of practical reason before he presented his theory of the two postulates, in his Critique of Practical Reason of 1788, but does not mention any further postulate in this Critique. In his sketch, Idea for a Universal History from a Cosmopolitan Point of View of 1784, from which we quoted earlier, he had first developed the idea of a "natural guarantee of peace" which he further elaborated in the text that constitutes the focus of our scrutiny.

Nature - or, as Kant also says, Divine Providence - cannot be regarded as futile in its course by anyone who is committed to the "highest good." Now it seems that the antagonism of natural interests constantly keeps man from achieving his highest destiny. But this is only the impression we get from a superficial look at things. In reality, the antagonism of egotistic interests is nature's invention to force mankind toward its ultimate harmony. It is conflict, not inertia which causes the highest achievements of man:

Thus are taken the first true steps from barbarism to culture, which consists in the social worth of man; thence gradually develop all talents, and taste is refined; through continued enlightenment the beginnings are laid for a way of thought which can in time convert the course, natural disposition for moral discrimination into definite practical principles, and thereby 
change a society of men driven together by their natural feelings into a moral whole. Without those in themselves unamiable characteristics of unsociability from whence opposition springs - characteristics each man must find in his own selfish pretensions - all talents would remain hidden, unborn in an Arcadian shepherd's life, with all its concord, contentment, and mutual affection. Men, good-natured as the sheep they herd, would hardly reach a higher worth than their beasts; they would not fill the empty place in creation by achieving their end, which is rational nature. Thanks be to Nature, then, for the incompatibility, for heartless competitive vanity, for the insatiable desire to possess and to rule! $!^{13}$

Someone who does not know the source of this text might be tempted to search through Adam Smith's The Wealth of Nations rather than in the writings of the theoretician of the "categorical imperative" for the verification of this passage. But one must be careful not to confuse the basic reasoning behind these lines. Kant, despite his many allusions to the (in his opinion) obvious progress of mankind in history, draws his argument for the guarantee of man's eventual sociability by Nature or Providence, in the final analysis, not from empirical reasons but, from the moral commitment to the highest destiny of man.

He puts the decisive question a little later, in the Seventh Thesis:

whether we are ... to suppose that Nature follows a lawful course in gradually lifting our race from the lower levels of animality to the highest level of humanity ... or whether we prefer to assume that, from all these actions and counteractions of men in the large, absolutely nothing, at least nothing wise, is to issue; that everything should remain as it always was, that we cannot, therefore predict if discord, so natural to our race, may not eventually prepare for us a hell of evils, however civilized we may be, perhaps by annihilating civilization and all cultural progress through barbarous devastation $(\ldots)$ - this question amounts to about the same as this: whether it is reasonable to assume a purposiveness of nature in parts and to deny it to the whole. ${ }^{14}$

Kant makes it clear that his answer to this alternative - there definitely is a purposiveness of nature and history in its totality! - follows from the evidence of the call to work toward the accomplishment of the "highest good" which implies that history on the whole cannot be futile. ${ }^{\text {is }}$ The reason why he does not explicitly state this assumption as a particular postulate of practical reason may be that he simply considers it as part of the postulate of the existence of God, the guarantor of a final harmony between morality and the laws of nature in his perpetual providence.

However, there is a fundamental difficulty implied in this postulate insofar as it claims a relationship between the natural egotism of man and his becoming moral. In the passage cited above, this implication is expressed as a change of "a society of men driven together by their natural feelings into a moralwhole." In a similar remark in the essay On Eternal Peace, Kant observes that even the 
actual states, which are far from perfectly organized, ... (approach) in their foreign relations ... that which the idea of right prescribes. This is so in spite of the fact that the intrinsic element of morality is certainly not the cause of it. (A good constitution is not to be expected from morality, but, conversely, a good moral condition of a people is to be expected only under a good constitution. $)^{16}$

Kant does not assert there to be an immediate moral improvement by way of natural force. Nature impels man only to be a good citizen, not necessarily a morally good person. ${ }^{17}$ But the fact remains that the same philosopher, who has made it so crystal-clear that there is an eternal gulf between the natural incentives of man and the Motivation by pure, moral reason, counts - in his philosophy of history - on a mere natural support of mankind in its striving toward the ultimate moral goal of the "highest good" (which, in the context of Kant's Religion Within the Limits of Reason Alone is equated with the "kingdom of heaven"). And this amounts to a support of morality by the drives of brute egotism. The psychological reason for this inconsistency may be found in the combination of an ethical rigorism with a deep pessimism concerning the use men actually make of their freedom, an outlook so natural to Kant. But this does not help to solve the dilemma.

As we mentioned earlier, it was J. G. Fichte who pursued Kant's idea of a "social contract among devils" most rigorously. He thus became subject to the same dilemma between an automatically achieved legality and the moral purpose of man. It is interesting to note, however, that at a time when Fichte (unlike his critics, Schelling and Hegel) still believed in the possibility of a just social arrangement out of the multitude of egotistic interests, he became aware of the decisive threat that this theory raised in respect to the consistency of moral reason - and the depth of this problem dawned upon him a little earlier and more vigorously than upon his critics. In the Third Book of The Vocation of Man of 1800, Fichte first describes the quasi-automatic accomplishment of a just society as the "purpose of earthly life." 18 But then he continues:

... the most despicable passions of men, even their vices and their crimes, often forward more certainly the good cause than the endeavors of the virtuous man who will never do evil that good may come! It seems that the Highest Good of the world pursues its course of increase and prosperity independently of all human virtues or vices, according to its own laws, through an invisible and unknown Power, just as the heavenly bodies run their appointed course independently of all human effort, and that this Power carries along with it, in its own great plan, all human intentions good and bad, and, with overruling wisdom, employs for its own purpose that which was undertaken for other ends.

Thus, even if the attainment of this earthly end could be the purpose of our existence, and if reason could answer every question about it, yet this end would not be ours, but the end of that unknown Power. We do not know at any given moment what is most conducive to this end; and nothing is left to us but to give by our actions some material, no matter what, for this 
Power to work upon, and to leave to it the task of elaborating this material to its own purposes. It would, in that case, be our highest wisdom not to trouble ourselves about matters that do not concern us; to live according to our own fancy or inclinations, and quietly leave the consequences to that unknown Power. The moral law within us would be void and superfluous, and absolutely unfitted to a being destined to nothing higher than this. In order to be at one with ourselves, we should have to refuse obedience to that law, and to suppress it as a perverse and foolish fanaticism. ${ }^{19}$ The struggle which resulted from this insight into the dilemma between legality and morality is very complex, as Fichte's later political writings exhibit. He has become famous or, I should rather say, notorious for only one extreme outcome of this struggle, namely the moral totalitarianism suppressing all independent legal concerns which seems obvious from part of his Addresses to the German Nation of 1808. At the point of history when Napoleon had not only buried, as it appeared to many a European thinker, all hopes for a republican constitution but also crushed Prussia, the last stronghold of German power, in his triumphal march toward Moscow, Fichte found words of inflammatory rhetoric which today, after the experiences of two world wars caused by the German Nation, have quite a different sound. I wish to choose two particularly illustrative examples of Fichte's harsh ideas for bringing a nation from the level of mutually arranged self-interest to moral unity.

The former systems of education took man's freedom of choice for granted. Fichte says, in his Second Address:

... in order to define more clearly the new education which I propose, I should reply that that very recognition of, and reliance upon, free will in the pupil is the first mistake of the old system and the clear confession of its impotence and futility. For, by confessing that after all its most powerful efforts the will still remains free, that is, hesitating undecided between good and evil, it confesses that it is neither able, nor wishes, nor longs to fashion the will and (since the latter is the very root of man) man himself, and that it considers this altogether impossible. On the other hand, the new education must consist essentially in this, that it completely destroys freedom of will in the soil which it undertakes to cultivate, and produces on the contrary strict necessity in the decisions of the will, the opposite being impossible. ${ }^{20}$

Then, in the Eighth Address, he develops his idea of the "love of fatherland": ... it must be love of fatherland that governs the state by placing before it a higher object than the usual one of maintaining internal peace, property, personal freedom, and the life and well-being of all. For this higher object alone, and with no other intention, does the state assemble an armed force. When the question arises of making use of this, when the call comes to stake everything that the state, in the narrow conception of the word, sets before itself as object, viz., property, personal freedom, life, and wellbeing, nay, even the continued existence of the state itself; when the call comes to make an original decision with responsibility to God alone, and 
without a clear and reasonable idea that what is intended will surely be attained - for this is never possible in such matters - then, and then only, does there live at the helm of the state a truly original and primary life, and at this point, and not before, the true sovereign rights of government enter, like God, to hazard the lower life for the sake of the higher... What spirit is it that in such cases may place itself at the helm, that can make its own decisions with sureness and certainty, untroubled by any hesitation? What spirit has an undisputed right to summon and to order everyone concerned, whether he himself be willing or not, and to compel anyone who resists, to risk everything, including his life? Not the spirit of the peaceful citizen's love for the constitution and the laws, but the devouring flame of higher patriotism, which embraces the nation as the vesture of the eternal, for which the noble-minded man joyfully sacrifices himself, and the ignoble man, who only exists for the sake of the other, must likewise sacrifice himself. ${ }^{21}$

However different from Fichte's ideas Hegel's philosophy may be, it congrues with the former to the point that a legality independent from the morality realized in a people must not be admitted. In other terms, a political freedom of the citizens according to the model of a social contract is not granted in Hegel's system. The sovereignty and power of a state lies totally in the hands of the monarch, the ultimate incarnation of the "absolute spirit" as it reveals itself in a particular epoch of history.

This fusion of moral and legal issues is not confined, however, to the rather conservative political theories of Hegel and the later Fichte. It is also essential to almost all revolutionary movements. Not only Marxism, which may be regarded as a further development of Hegelianism, but already the particular brand of theory of a social contract which became constitutive for the French Revolution, entailed this attempted harmony of legality and morality. In his essay, The Rebel, Albert Camus asks:

What, in fact, is virtue? For the bourgeois philosopher of the period it is conformity with nature and, in politics, conformity with the law, which expresses the general will. "Morality," says Saint-Just, "is stronger than tyrants." It has, in fact, just killed Louis XVI. Every form of disobedience to law therefore comes, not from an imperfection in the law, which is presumed to be impossible, but from a lack of virtue in the refractory citizen. That is why the Republic not only is an assembly, as Saint-Just forcibly says, but is also virtue itself. Every form of moral corruption is at the same time political corruption, and vice versa. A principle of infinite repression, derived from this very doctrine, is then established. ${ }^{22}$

Let us halt at this point and look back at what we have said. After the breakdown of the medieval cosmos, in which rights and morals were equally embedded in the last horizon of a mystical "Body of Christ," i.e., correlated under the auspices of a divine and hierarchical order, modern political theory made attempts at constructing a new social justice out of the fragmented elements that were left - the atoms of society, the multitude of individuals, 
each with his egotistic desires but also his legitimate claim of freedom. The more rigorous theoreticians of the social contract, like Hobbes and, in the context of political economy, Adam Smith, being aware of the difficulty of assuming a certain stable moral potential of man as a premise for their reasoning, were rather inclined to count on a certain rationality inherent in nature which would bring forth a state of justice out of the sheer antagonism of forces. We found the most concise abbreviation of this strand of political thought in Kant's idea of a "social contract among devils" but discovered two basic weaknesses of this theory. (1) There is no chance of a totally satisfying self-arrangement of conflicting private interests. A perfect control over the highest power cannot be guaranteed and, as we may add, even if a satisfactory mutual arrangement of egotisms on the level of the most powerful in society were achieved, this would not preclude the suppression and exploitation of lower classes of slaves in the same society. (2) In the perspective of morality, the assumption of a mechanistic balancing of conflicting interests toward a state of eternal peace seems contradictory to the commitment of moral reason to the social cause. I cannot trust the higher rationality of nature exhibited in the self-centered interests of men and, at the same time, work at overcoming this egotism. The complete abandoning of the distinction between legality and morality, however, proves even more disastrous to the fate of society, as we have seen from the development of German Idealism in its reaction to the lacunae in Kant's political theory.

What conclusion, then, is to be drawn on the presuppositions of modern man who cannot return to the medieval dialectic between popes and emperors, a struggle in which the problem of the mutual independence and correlation of morality and legality seemed to have found a viable solution?

One thing seems to be obvious. The fact that the problem of constructing a just society on the basis of a social contract does not allow for a perfect solution is no sufficient reason to abandon this theory altogether. It contains at least one necessary element for the establishment of any state of right: the attempt to guarantee the "formal freedom" of the individual, i.e., his right to be forced to nothing to which he has not given his consent. The theory becomes questionable where it confesses the "formal freedom" of the individual with his actual exercise of freedom, which is normally centered upon egotistic concerns, i.e., committed to a matter which does not deserve the protection of the law. The main problem is that you cannot give the necessary guarantee for the formal freedom of men without automatically protecting, at the same time, a good deal of their egotism, the reason for this being that "formal freedom" is but an abstract, although important, idea while in matters of fact formal freedom is either committed to a moral or an immoral matter and, alas, more often to the latter.

From there one fundamental task of political theory may be concluded: to establish a state of law in which as much formal freedom as possible is guaranteed together with as little protection as possible of mere egotistic concerns. 
The other fundamental task for political theory results from the concept of the "highest good," i.e., the ultimate end of moral concerns as a common goal of all. It may be formulated like this: Create a system of law which allows for as much contribution as possible from the total morality given in the society under this law, toward the accomplishment of the highest common good, and also provide for or protect the necessary institutions which further this morality and its influence upon society on the whole.

These two principles are theory, elements for a sound political theory as I believe. In practice, things are more confusing. There are people who have become highly aware of their individual rights, but are utterly mixed-up when it comes to the question: what is materially good beyond the legally granted free play of formal freedom? And there are others who have not yet developed a keen sense of their individuality and can therefore easily be drawn into more or less passively accepting a prefabricated concept of what is the common good - and, since the development of technical means allows for the efficient institutionalizing of the power of the Big Brother, will hardly ever escape from what they once have been submitted to. We shall have to face this reality without losing sight of our basic goals, we, a people neither of devils nor angels, but of men and women who feel the call to something so precious and dangerous as freedom.

University of Freiburg

\section{Notes}

1 Tr. by Carl Joachim Friedrich, in the Appendix to his work Inevitable Peace, Cambridge, Massachusetts (Harvard University Press), 1948, p. 244. For someone who has not frequented Dutch or German restaurants, it should be noted that the word "Zum" which Kant uses in his title "Zum ewigen Frieden," is often found on such signboards, cf. e.g. "Zum roten Ochsen" ("Red Ox"), "Zum Hl. Georg" ("St. George"). etc.

${ }^{2}$ Original edition of 1788 , S. 54, Tr. by Lewis White Beck, Indianapolis-New York (Bobbs-Merrill), 1956, p. 30.

${ }^{3}$ Ed. by Charles W. Hendel, Indianapolis-New York (Bobbs-Merrill) 1955, p. 100.

${ }^{4}$ Original edition of 1795, S. 61. I used for my own translation Friedrich, l.c., p. 263, and the translation by Lewis White Beck in his edition Perpetual Peace, Indianapolis-New York (Bobbs-Merrill), 1957, p. 30.

s 358e-359a, I made use of the translation by W. H. D. Rouse, Great Dialogues of Plato, New York (The New American Library of World Literature), 1956, p. 156.

${ }^{6}$ Leviathan, Pt. I, Ch. xi.

${ }^{7}$ Cf. Jacob Viner, "Adam Smith and Laissez Faire," in: Adam Smith, 1776-1926. Lectures to Commemorate the Sesquicentennial of the Publication of "The Wealth of Nations", reprint New York (Augustus M. Kelley), 1966, p. 119.

${ }^{8}$ Orig. ed., S. 58f; Perpetual Peace, I.c., p. 29. 
${ }^{9}$ Orig. ed., S. 64; Perpetual Peace, l.c., p. 32.

${ }^{10}$ Cf. F.W.J. Schelling, System des Transcendentalen Idealismus (1800), Sämtliche Werke III, S. 584f; G. W. F. Hegel, "Über die wissenschaftlichen Behandlungsarten des Naturrechts . . ., "in Kritisches Journal der Philosophie, 2. Bd., 2. Stück, 1802, reprint Hildesheim (Olms) 1967, S. 52-54; J. G. Fichte, Addresses to the German Nation (1808), ed. G. A. Kelly, New York and Evanston (Harper \& Row) 1968, pp. 96f (Sämtliche Werke VII, S. 363f); Rechtslehre of 1812 (SW X, S. 632f).

${ }^{11}$ Orig. ed., S. 397, cf. Imanuel Kant, On History, ed. by Lewis White Beck, Indianapolis-New York (Bobbs-Merrill) 1963, pp. 17f. In Beck's text, the translation of the last sentence is missing.

12 Orig. ed., S. 65, Perpetual Peace, 1.c., p. 32.

${ }_{13}^{13}$ Fourth Thesis, Orig. ed., S. 393f, On History, 1.c., p. $15 \mathrm{f}$.

${ }^{14}$ Orig. ed., S. 400f, cf. On History, l.c., p. 20, which we used for our translation.

${ }^{15}$ Cf. On Eternal Peace, orig. ed., S. 51 (Perpetual Peace, l.c., pp. 25f); "On the Common Saying: "This may be true in theory, but it does not apply in practice" (1793), in: Kant's Political Writings, ed. by Hans Reiss, tr. by H. B. Nisbet, Cambridge (University Press) 1970, pp. 87-92 (orig. ed., S. $271 \mathrm{ff}$ ); and especially the conclusion of Kant's theory of right in the first part of his Metaphysics of Morals (1797).

${ }^{16}$ Orig. ed., S. 61, Perpetual Peace, 1.c., pp. 30f.

${ }_{17}$ Ibid., S. 60, p. 30; cf. Religion Within the Limits of Reason Alone, tr. by Th. M. Greene and H. H. Hudson, New York (Harper \& Row), 1960, p. 86; ed. K. Vorländer, Hamburg (Meiner), 1956, S. 101.

${ }^{18}$ Ed. by R. M. Chisholm, Indianapolis-New York (Bobbs-Merrill), 1956, pp. $113 \mathrm{f}$ (Sämtliche Werke II, S. 278).

${ }^{19}$ Ibid., pp. 115f (SW II, S. 279f).

${ }^{20}$ Ed. Kelly, l.c., p. 17 (Sämtliche Werke VII, S. 281).

${ }^{21}$ Ibid., pp. $119 \mathrm{f}$ (SW II, S. 386f).

${ }_{22}$ Tr. by Anthony Bower, New York (Vintage Books), 1956, p. 123; L'homme révolté, Paris (Gallimard), 1951, p. 156. 